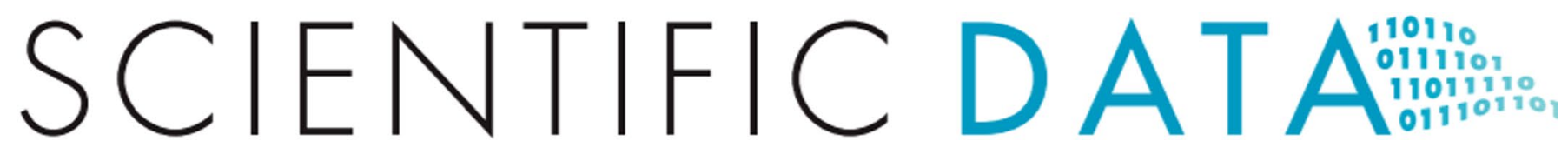

Check for updates

\title{
Author Correction: A rasterized building footprint dataset for the United States
}

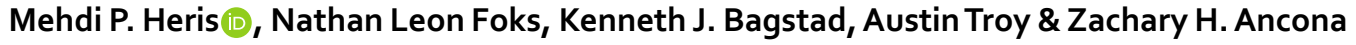

Correction to: Scientific Data https://doi.org/10.1038/s41597-020-0542-3, published online 29 June 2020

The original version of this Data Descriptor incorrectly labelled Figure 4 as Figure 5, Figure 5 as Figure 6 and Figure 6 as Figure 4. The ordering of Figures 4, 5, and 6 has now been corrected in both the HTML and PDF versions of this Data Descriptor.

(c) (i) Open Access This article is licensed under a Creative Commons Attribution 4.0 International License, which permits use, sharing, adaptation, distribution and reproduction in any medium or format, as long as you give appropriate credit to the original author(s) and the source, provide a link to the Creative Commons license, and indicate if changes were made. The images or other third party material in this article are included in the article's Creative Commons license, unless indicated otherwise in a credit line to the material. If material is not included in the article's Creative Commons license and your intended use is not permitted by statutory regulation or exceeds the permitted use, you will need to obtain permission directly from the copyright holder. To view a copy of this license, visit http://creativecommons.org/licenses/by/4.0/.

(c) The Author(s) 2020 